\title{
METAUTOPIC DISCOURSE IN ANTOINE VOLODINE`S NOVELS
}

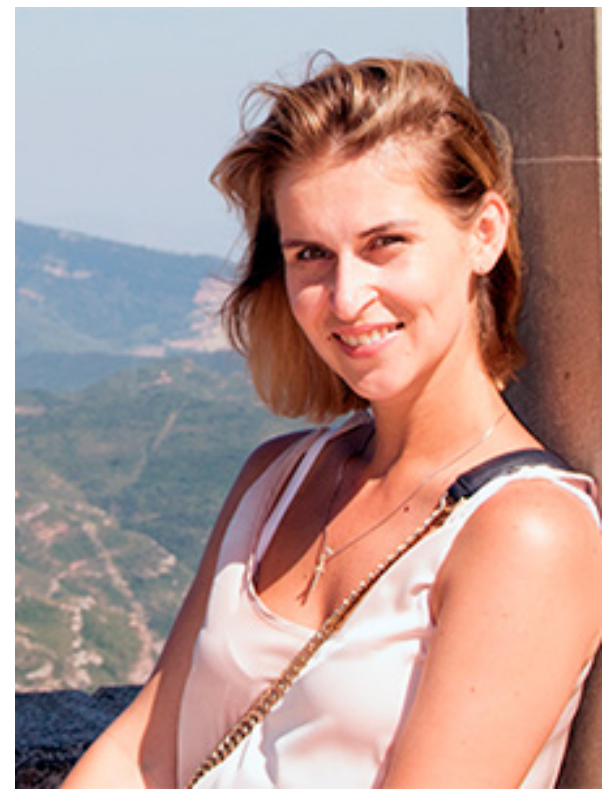

\section{@ Victoriya CHUB}

\section{Senior Lecturer}

Department of Romance Philology and Translation

V. N. Karazin Kharkiv National University

4 Svobody Sq., Kharkiv, 61022, UKRAINE

email:vita.chub@gmail.com

ORCID: 0000-0002-2822-1046

\section{Abstract}

Poetical dominants of the novels by A. Volodine appear as the combination of elements of historical, political, science fiction discourses, aimed to represent the irreal world as the possible one. Within the aesthetic space of postmodernism, A. Volodine develops the reflection on the problem of relations in the triad of human/society/civilization in a fictional form. This original genre form combines various utopian modus elements: dystopian one in the denial of the utopian project and showing the individual's impersonality and social decline in the conditions of utopia ("Minor Angels"), dystopian one - in the negative reality representations similar to the modernist detachment and «black novels» ("Dondog"), counter-utopian one - in the ironic interpretation of the $20^{\text {th }}$ century utopia/dystopia tradition in terms of postmodernist mindset ("Bardo or not Bardo"). Such modifications resulted in the attribution of A. Volodine`s postmodernist novels as meta-utopia that is the architextual form based on the utopian canon, a kind of parody and rethinking of the utopia.

Keywords: AntoineVolodine, post-exoticism, meta-utopia, dystopia, utopic discourse

Antoine Volodine (born 1950) is one of the brightest contemporary French writers, the author of 43 prose works. His novels at the same time update and destabilize the context, actualizing the need to consider literary work as a socially significant activity and as a reflection on the historical epoch, to combine political and intellectual 
practices, to revise the novel tradition. In "the end of postmodernism" situation, he represents himself as the creator of a new artistic paradigm, "post-exoticism”, which is "alien" to all known trends and directions. The matrix for the creation of postexotic novels is the "voices" of prisoners and victims of concentration camps, who choose speech as a way of preserving memory and human existence in the "postexotic" world. In the fictional world of A. Volodine, the latter destroys the barrier between the real and the imaginary, the author and the character, the past, present and future in order to revive the reader's reflection on the problems of creativity, collective memory, and the history of the $20^{\text {th }}$ century.

The problem of determining the essence of "post-exoticism" and the place of "postexotic" novels in the French and world's literary process appeared as the most controversial. The tendency to comprehend A. Volodine's novels in the discourse of the fantastic (Roche, 2013) gave way to recognition of his "isolation" and "inflexibility" in the literary context (Briot, 1995), (Huglo, 2003). The discoursegenre identity and hybridity of A. Volodine's prose were determined by the scientists as a "xenogenre" (Шервашидзе, 2007) or "baroque" (Детю, 2008) form. The researchers also analysed "post-exotic" novels in the aspect of certain discursivegenre dominants, and revealed historical (Briot, 1995), political (Richard, 2012), utopian (Epelboin, 2013), (Lamarre, 2014), (Huglo, 2003) ones. All of them agreed that the prose by A. Volodine updates the literary context, but the discursive-genre form of his novels did not receive enough determinancy.

Thus, the problem of specifying the discursive-genre form of A. Volodine's novels is generated by their "multi-discursiveness", combination of genre elements. Moreover, the problem is complicated by the positioning of these works as "alien" in relation to well-known literary classifications - as the author himself claims in "Post-Exoticism in Ten Lessons, Lesson Eleven”: "Due to your intellectual laziness, you consider post-exoticism to be one of the aesthetic trends amongst others, an odd version of magical postmodernism... while post-exoticism for your literature is...” (Volodine, 1998: 33).

The aim of our research is to identify and analyse poetical specifics of A. Volodine's novel prose as artistic embodiment of the genre-discursive parameters of postmodern meta-utopia. The material of the research is A. Volodine's key novels of different periods, namely: "Minor Angels" ("Des anges mineurs", 1999), "Dondog” (“Dondog”, 2002), "Bardo or not Bardo" ("Bardo or not Bardo", 2004) and "Radiant Terminus” (“Terminus radieux”, 2014). 
The complexity of genre-discursive definition of works lies in the historical mobility of the object of study itself, which becomes particularly relevant in post-modern era. The category of "genre canon" is subjected to revision in the context of postmodern "decanonization", refusal of authority, irony, and struggle with value centres. Refusing to adhere to consistent genre forms, "the writer often considers these features as an area for the formation of additional game moments in the text" (Бовсунівська, 2010: 20-21). At the forefront, one can see a more flexible category of discourse, which came to literary studies from linguistics and philosophy. In the poststructuralist paradigm, discourse is identified with speech as a field of expression - according to M. Foucault, discursive practices are a set of historically established rules and constraints that form the field of expression (Фуко, 2004), and the text is considered as the embodiment of discourse (or several discourses) taking into account the object, subject and recipient. Therefore, a literary work is a form of aesthetic discourse.

Let us dwell on the understanding of discourse as the collective name of a certain domain of speech practice, which has a number of differentiated features; and the genre as realization of its properties. In postmodern literature, the genre category loses its signs of a stable form and is realized within discursive practices. In the present situation, any literary work as a text cannot be separated from its communicative intention and existence as an act of expression; it exists within the framework of aesthetic / artistic discourse, which imposes certain restrictions on it. In this context, there is a merger of discursive and genre elements as regulatory constructs and means of the theological implementation of this act, respectively. In addition, one should bear in mind that in the post-modern era a literary work as a product of artistic discourse intersects with other discourses (historical, political, etc.). Consequently, the poetic analysis should combine both genre and discursive elements, the coexistence of which determines the form and content of the literary work.

A. Volodine's prose obviously has signs of utopian / anti-utopian discourse, represented through the prism of postmodern consciousness and embodied in a novel form. However, critical research presents variations between two definitions of the writer's novels. Some scientists see them as “utopian” (Lamarre, 2014), (Huglo, 2003), (Шервашидзе, 2007), and they emphasized the study of utopia in "postexotic" novels as a social ideologue of the $20^{\text {th }}$ century, which may still have a positive realization as poetization of revolutionary ideas and mythologization of history can be still traced. While other scientists view the novels as "anti-utopia" (Детю, 2008), (Epelboin, 2013) due to the nature of time-spatial features or "counter- 
utopia” (Ruffel, 2007: 82), which relied on political nature and hyperbolized realism of the "post-exotic" world. M. Lamarre in his comparative study of novels by A. Volodine and O. Rolin determined utopia " $<\ldots$..> as a seductive image embodied in a narrative of a political character $<\ldots>$ where irony is combined with melancholy, which reveals the extremely ambivalent nature of utopia” (Lamarre, 2014: 13).

Social and political events of May 1968 refreshed a critical reflection of utopian thought: a situation consonant with the epoch appeared in literary practice. It meant, "Researchers are no longer seeking relic of insane hopes, but the foresight of "a new thinking”, so necessary in the $21^{\text {st }}$ century” (Чаликова, 1991: 7-8). In the 1970 s, "New Philosophers", a union of young intellectuals with the left-wing views (A. Glucksmann, B. A. Levy, etc.) was formed in France. The union based their views on doubt and exposure of the excessive seizure of power in totalitarian countries. "Anti-totalitarian” critique of "New Philosophers” was centred on crimes in the USSR (O. Solzhenitsyn's works were the artistic material), was fed by political events (Portuguese Revolution of 1975, immigration processes in Vietnam ("Vietnamese boat people"), the tragic fate of dissidents in the countries of the Eastern Bloc, in particular in the USSR, crimes of Maoist China, etc.), and eventually emerged as the guiding principle of the French intellectual thought of this period (Lamarre, 2014: 22). These events obviously influenced Volodine's world-view position and were later comprehended in his novels: Portuguese realities appear in the novel "Lisbon, last frontier", concentration camps - in the novel "Dondog", etc.

The end of the 1970s marked the "end of utopia" in French literature (Lamarre, 2014: 20) (the key issues of this time French novel are comprehension of history and present days, reflection of social disappointment in civilization processes and inability to achieve "utopian" ideals). S. Bezchotnikova analyses "anti-utopias" of this period, in particular, the works by P. Boulle, R. Merle, M. Tournier in the framework of Western European "existential anti-utopia” as a continuation of the tradition of A. Camus (Безчотнікова, 2008). The concept of utopia / anti-utopia in French literary discourse was introduced by A. Cioranescu (borrowing it from the socio-critical / socio-political) and defined as a critical reflection on the history and future of mankind in artistic form: "the way of representing imaginary state of things as the factual one in order to analyse it and its consequences" (Cioranescu, 1972: 22). In the French novel of the second half of the $20^{\text {th }}$ century, the researcher revealed a tendency "to demystify the idea of progress as a positive phenomenon" and "to replace the image of a perfect and stable positive utopia for the representation of the utopian process” (Cioranescu, 1972: 40-41). 
Formation of this tendency dates back to the time of the emergence of a postmodern paradigm ("Literary Journal" on "The End of Utopias" published in 1978, and "The Postmodern Condition" by J.-F. Lyotard in 1979), so the comprehension of the collapse of utopian ideals takes place in the framework of a new artistic direction. "Anti-utopias" combine the recognition of events (connection with the historical epoch) and artistic forecasting, "organically correspond to the worldview of a modern person” (Федух, 2015). Such discourse-genre form fits into the parameters of postmodern consciousness, which is characterized by "deep frustration in the surrounding reality, the cult of individual freedom, a critical analysis of the past and the present in all spheres of human existence” (Федух, 2015).

Along with the term "anti-utopia”, literary critics use such terms as "negative utopia", “dystopia”, “cacotopia”, “pseudotopia”, “а warning novel” (Козьмина, 2005). S. Shishkina notes that these concepts are mostly "used absolutely synonymously, without clarifying the fundamental difference among them” (Шишкина, 2007: 207), and S. Kovtun confirms that "from the point of view of poetics, they represent varieties of the integral artistic structure" (Ковтун, 1999: 70). French researcher K. Braga suggested using the "generic" term "utopia" to denote the utopian genre, in which he distinguished four types: eutopia, utopia, dystopia and anti-utopia (Braga, 2006).

Thus, in the postmodernist situation of hybridization of genre forms, the emphasis is shifted from the opposition of "utopian forms" to their comparison and coexistence within a single work. On the foreground appear common genre signs and aesthetic principles of utopia / anti-utopia, namely the image of the collective / organization / society as models of the state system; abandonment of the present, expressed in radical forms of escapist withdrawal to the closed space and other time; collective nature of a utopian goal (Воробьева, 2009). A combination of positive and negative interpretation of the socio-political plot is characteristic of the beginning of the $21^{\text {st }}$ century, when nostalgia for utopias was imposed on the assertion of their historical defeat, and implementation of utopian projects remains a dream and coexists with "anti-utopian fear".

At the turn of the century, the utopian mode of culture is undergoing a transformation of the functions of anti-utopia, which "fulfils prognostic, preventive and diagnostic functions in the fiction literature of the postmodern age, posing not only a means of 'liberation from utopianism', 'manifestation of apocalyptic attitude', but also an artistic technology of diagnosing the reaction of social consciousness to a certain utopian idea” (Безчотнікова, 2008). The need to invent a new form of collective identity, a new ideological paradigm, comes to change the stage of "contraction of 
legitimation and alternatives to dominant ideology in 1980-1990s" (Безчотнікова, 2008). The metagenre nature of dystopia determines its ability "to form architextual and metatextual forms based on a genre canon” (Безчотнікова, 2008).

G. Morson was one of the first to use the term "meta-utopia" to define new forms of utopian discourse (Morson, 1981). He understands "anti-utopian meta-artistry", tracing it both in a parody nature of dystopia (re-thinking texts of other genres: fantastic, historical and, indeed, utopian) and in "reflexive games" (the subject of which is utopian consciousness) inherent in this genre form. The researcher discovers "meta-artistry" in dystopias by J. L. Borges and Y. Zamiatin, and notes that this feature is a moving force in the evolution of the genre. G. Morson states the unity of "utopia" and "anti-utopia" in frames of interpretation of the causes and consequences of the "shift" between social imagination and social fact. This principle of dialectical connection, the inseparability of utopia and dystopia lies at the heart of the concept of metagenre of utopia (Morson, 1981: 111).

Consequently, contemporary anti-utopian novels bear the presence of the conceptual connection with utopia (in the form of parody / criticism / reflection / satire, etc.). Thus, this presence transforms critical rhetoric into the field of meta-utopia as a metagenre of utopia and anti-utopia. As the common object of the image of "metautopia”, theorists define "a perfectly beautiful (utopia) or a perfectly negative (antiutopia) common world”. In postmodern discourse, this approach conceptualizes the overcoming of genre regulation, actualized in the situation at the end of the $20^{\text {th }}$ century, when anti-utopian tendencies go beyond the genre and "amplify throughout the literary space"; absorb or include themselves in genres of science fiction and fantasy, detective and political novel; collective consciousness becomes anti-utopian, "gives rise to distrust of any reforms and projects to improve life" (Воробьева, 2009)).

The attribution of "meta-utopia” as "metagenre” induces its interpretation as a supergenre structure that absorbs more fields of literary phenomena, overcomes an attachment to a certain kind. Metagenre is not a conventional form, but it is "tied" to a certain epoch / cultural context, and therefore it is historically limited. Thus, metagenre of "utopia" absorbs generic and genre features, is a conditional "supergenre matrix" (Подлубнова, 2007) (the core of which is determined by the aesthetic priorities of the utopian consciousness) and admits a poly-genre structure. This form undergoes a critical reflection of the utopian ideals subjected to scepticism in the postmodern consciousness. 
Hence, the ambivalence of utopia and anti-utopia appears as a sign of "a new utopian discourse" (Воробьева, 2009) and becomes the methodological basis for the concept of meta-utopia. Meta-utopia preserves a number of poetic signs of utopia / antiutopia, but reveals the "oxymoronism of utopian consciousness" (Козьмина, 2005), has the character of its tragic / dramatic comprehension on the background of actualization of existential issues.

Consequently, meta-utopia is considered as a super-genre structure that absorbs the signs of utopian and anti-utopian discourses, develops within a postmodernist (and post-postmodernist) novel, and has a number of persistent problem and poetic features.

Understanding the anti-utopian nature of idealized social constructs and political concepts in the framework of postmodernism is reflected in the prose by A. Volodine, P. Guyotat, V. Novarina, O. Rolin, and others. With their inherent engagement, these writers are discussing defeat of revolutions and utopian projects and update the genre-discursive form of utopia / anti-utopia. They turn to the memory of generations in order to revise the principles which underlie those utopias that have already collapsed in the modern world. This form of utopia restores the connection between the present and the past, while at the same time projects into the future - restoration of time-spatial features, the relationship between the fictional world and the real world is new to the postmodern paradigm - in the context of the postulated "death of the novel”, this trend demonstrates aesthetic and theoretical update the novel form.

In Ukraine A. Volodine is still a little-known writer. His novels have not been translated into Ukrainian yet. In scientific discourse, his name appears only in the monograph "Alchemy of the living word. The French novel of 1945-2000" together with the names of J. Echenoz, P. Quignard, J.-P. Toussaint, M. Houellebecq. In this work, such poetic dominants of the author's novels as irreality of time space, metatextuality, updating of narrative strategies and genre forms were accentuated. At the same time, one emphasized the prevalence of fantastic discourse elements and socio-political issues. Therefore, although Ukrainian literary studies are already positioning A. Volodine as innovator and indicative phenomenon of modern literature, the discourse-genre attribution of his works is not specified.

A poetic analysis shows that the fantastic component is not a discourse-genre dominant of A. Volodine's works, which tends to utopian discourse, but the dominant is still far from the canonical form of the genre of utopia or anti-utopia. This fact does not contradict modern literary theories in any way. Thus, S. Shishkina dwells on the close relationship between the forms of the fantastic and the utopian (the researcher 
observes that techniques of the fantastic "are still present in utopia and anti-utopia but are not ideologically or plot dominant” (Шишкина, 2009: 126). Speaking about the solution to the problem of the relation between two discourse-genre paradigms (utopia / anti-utopia and science fiction), O. Vorobyova supposes that "anti-utopian transformations in the field of science fiction are clear and even natural, since the boundary separating "the pure" scientific plot from "the social one" is very subtle, dialectical” (Воробьева, 2009: 174). In the context of the novel, at the turn of the $20^{\text {th }}$ and $21^{\text {st }}$ centuries, the utopian form comes to the foreground, "becomes a way of expressing the literary self-consciousness of a nation, acquires the scope and stereoscopy” (Шишкина, 2009: 128).

The combination of elements of science fiction and alternative history defines the proximity of the novels "Minor Angels", "Dondog”, "Bardo or not Bardo" to utopian discourse. Their socio-political and philosophical issues are a sign of dystopia as a negative utopia, which "refutes this happy version by its logical continuation and bringing to a tragically absurd end” (Воробьева, 2009). A. Volodine’s novels are а form of updating the utopian mode through the withdrawal from the "pure" genre form of utopia / anti-utopia, the combination and rethinking of the collapse of the utopian idea in metagenre parameters, and can therefore be attributed as "postmodern meta-utopia”.

The anti-utopian component is present among post-apocalyptic signs of the chronotope: "On the other side of the broken windows is the city, there is no movement in it. When the wind blows, red dust travels along the ground and gathers in moving snakes of the red colour - they say they are the same on Mars. The sky $<\ldots>$ lost its colour" (Volodine, 1999: 119); "There is nothing else, the whole world is dead" (Volodine, 2003: 324); "a lama appears on the scene of the catastrophe to support the dead and their families" (Volodine, 2004: 126). The same happens with the motive of disappearance / degradation of human society: "we wanted to know if there are men and women, Yurubi, Quechua, Orochis somewhere far away" (Volodine, 1999: 167); "The presence of cockroaches testifies to the fact that one day there were people, and there was life, and together with people and life there was garbage and food" (Volodine, 2003: 95), "You are the same as us, as everyone else. All are the same. You, me ... I cannot claim that I'm really a person. I do not know anything about it” (Volodine, 2004: 217).

In the novel "Radiant Terminus", the author concentrates poetic dominants, available in his previous works (in particular, "Minor Angels", "Dondog", "Bardo or not Bardo"). The main idea of the work is destruction of an ideologically lost reality and it predetermines its anti-utopian character. The chronotope of "Radiant Terminus" is 
a phantasmagorical world between life and death, which after the defeat of the communist political regime will inevitably move to the apocalypse. In a single surviving urban centre (the capital of Orbis) capitalist barbarism prevails and civil war continues. Taiga, steppe, impenetrable forests are gaining space where human civilization used to exist - large cities, kolkhozes (collective farms), nuclear stations: "There was something eternal in the panorama. The vast sky was hanging over boundless meadows <...>. The ruins of a former kolkhoz are seen under the slope. Fifty years ago, there was a centre of settlement, but then agricultural buildings were affected by time. Barracks, pig farms, warehouses collapsed. Only a nuclear power unit and some monumental gates were kept" (Volodine, 2015: 11-12). But nature is not friendly to man; it acquires hostile and mortal signs: "Taiga is never to become a refuge, an alternative to death or camps. It's an endless space where man has nothing to do. There are only shadows and dangerous meetings. If you are not a beast, you will not be able to survive there" (Volodine, 2015: 13).

The romantic world is politicized, directed to the imaginary ideas of progress and freedom, but is constantly approaching the apocalypse or even has already survived it. The statement of the defeat of revolutionary plans, the death of society and man make one consider not only this novel, but also other works by A. Volodine in the context of anti-utopian discourse. His prose is characterised by depersonalization, specific modelling of the chronotope, conflict between man and society, representation of the negative vision of the future (the defeat of the egalitarian utopia, and the prospect of mankind's death) correspond to the problematic poetical parameters of dystopia.

At the same time, on the level of narrative tools one can observe a transgression of narrative constructs, instability of the narrative authority, distortion and uncertainty of time-space coordinates, thanatological and escapist motifs, figurativeness of the de-aesthetic, and others. Specificity of motives and images, isolation and postapocalyptic chronotopes, "de-aesthetization" of fictional space, depersonalization and stratification of narrative instances in A. Volodine's novels show mortal (thanatological and existential) reflexion which is key to the writer's art and at the same time compliant with the "apocalyptic" tension of modern era. Mortal topic becomes an instrument for implementing the "post-exotic" project of the writer as an opportunity to look beyond national and cultural boundaries and to express the history of the $20^{\text {th }}$ century, common for everyone, in an artistic form.

The novels by A. Volodine at the ideological level are really compliant with the concept of anti-utopia as a critical image of the utopian society, self-reflection of the utopian genre. Taking in the tradition of dystopia by Y. Zamyatin, G. Orwell, 
A. Platonov, O. Huxley, they update the problems of collective memory, dehumanization of the personality, the opposition of the person to society, the prospect of mankind's extinction.

In his "post-exotic" project, the writer expresses a total protest against the reality, society, utopian socio-political concepts. In the present state of society he reveals a tendency for depersonalization, loss of personality, comprehends the tragic experience of history and the collapse of utopian theories, makes predictions about the future of mankind, using phantasmagorical mutations of tragic events that reflect the negative tendencies of the history as a background.

Such metaphorical representation of the real world in the form of something fantastic is a sign of the very (anti)utopian (contrary to the fantastic) genre. A. Volodine implements in an artistic form the "anti-utopian" character of social thinking as the result of comprehension of socio-political disasters and perspectives of the further existence of mankind. The absence of the definite model of the "pseudo-perfect" world in the novels, the dramatization of consciousness, the comparison of utopian concepts with reality in the novels prove significant changes within the dystopian novel. As a product of the "postmodern epoch", the novels of A. Volodine diverge from the canonical genre form of "anti-utopia” (Y. Zamyatin, O. Huxley, etc.).

They are written under historical conditions, when utopian attempts to realize the "ideal" society have already been reversed (the collapse of the Soviet Union, the Chernobyl disaster), and this fact is reflected in the plot of the story.

Taking the "shift of fantastic elements towards reality" into consideration (Воробьева, 2009) (what was regarded as phantasmagoria in the early twentieth century, at the end - turned into history), the actual problem moves from prevention of the catastrophe to understanding and overcoming its consequences. M.-P. Huglo also defines post-exotic novels as utopian (Huglo, 2003: 95), but states that it is impossible to categorize their subgenre within the range of forms of "modern" utopia: "In Volodine's works utopia is fitted into a complex and paradoxical discursive space” (Huglo, 2003: 95)

The story gets the "utopian" continuation in the novels of the writer only in the discourse of dreams, speeches of the dead and the shamanic trance. Ultimately, at the ideological level, the "utopianess" of A. Volodine's novels turns into the interpretation of the only possibility of mankind's salvation in the form of eternal life (even if it involves the loss of human appearance, transformation into an animal or a "non-human being", the metamorphosis of a human being as a result of oniric and shaman practices, impossibility of existence of society, extermination of the 
"civilization" chronotope and its return to the original form) and philosophical and religious practices (Bardo).

Thus, in the ruined, dying or already dead "post-exotic" world, the two hundred year old "were building their plans for the future. They already knew that they would never die, and they worried that humanity had entered into practically the final phase of its decline, whereas all the conditions had long been formed for the prosperous present or almost prosperous” (Volodine, 1999: 21).

Dondog, during his stay in the camp, states that "real prospects henceforward only death could open" (Volodine, 2003: 264). A similar idea is found in the novel "Bardo or not Bardo": "neither revolution nor "Grandmother"” died, they "pass Bardo at the very moment... She will revive..." (Volodine, 2004: 31) and then "The end of inequality will be put everywhere" (Volodine, 2004: 37).

And Dadokian and Schmollowski dream to stay in Bardo, "to sabotage this story with matrices", because "it's all unbearable - to be born again, to re-integrate into the world of prisons, refuges, the rich and spiders" (Volodine, 2004: 190), so they decide "To build here a world in which one can live”, "a pleasant refuge, landscape", "to reorganize Bardo at their own discretion” (Volodine, 2004: 191).

This ontological coincidence of the end and the beginning is reflected on the ideological level as well as at the poetics one: Bardo is not only a "world that imitates death", but "the world that precedes birth", “a journey that leads to the revival" (Volodine, 2004: 140-141).

In the novel "Radiant Terminus" against the background of dystopian, negative development of the utopia, there is a motive for finding the possibility of survival, the return of the utopia: "Meme Udgul $<\ldots$. > knew that she had sacrificed herself, had given her own health and life for the sake of the future welfare of the community, for the sake of the happy future of children and grandchildren - her own, or someone else's, because she had been warned that radiation would doom her to be childless. $<\ldots>$ But, unlike other heroes, men and women who suddenly disappeared, she continued to live" (Volodine, 2015: 40).

Bagda Dolomides, who buried her husband, decides "to leave the hellish world of the factories and look for a better life, even if it meant exposing herself to numerous dangers while travelling through taiga” (Volodine, 2015: 196). The protagonist of this novel, Ellie Kronauer (A. Volodine's heteronym), a deserter soldier, after the downfall of the Second Soviet Union, goes to a forced trip to the steppes: "He remembered where from he saw some smoke overnight, and went there to that hypothetical village. There was nothing else on his mind” (Volodine, 2015: 68) and 
eventually comes across a commune Radiant Terminus, that was not on the maps. Located on a nuclear reactor, this place is inhabited by mutants. Soloviei runs them, a shaman with supernatural abilities, who can see dreams of other people himself or send them to oniric travels.

Iliouchenko, a combat friend of Kronauer, is moving but finds a train, where halfdead passengers "told him about the existence of a commune where they went to spend their last days there" (Volodine, 2015: 194). Iliouchenko says that "such destination suits him" (Volodine, 2015: 194), and "jumps into the train that goes to a better world, to an ideal commune - anywhere” (Volodine, 2015: 217).

The purpose of this journey is illusory: "Go ahead with the soldiers. Along the track. In the end, you will settle down somewhere. The distances are large, but you will always get somewhere " (Volodine, 2015: 178), but the aim becomes obsessive, like any utopian idea: "Everyone thought about one thing: how to get to the commune as soon as possible, the solitary confinement cell or something similar, to be together behind a barbed wire one day” (Volodine, 2015: 207).

Thus, there are two loci in the novel that retain the signs of social organization of life - the farm and the commune. In fact, the "radiant terminus" has little to do with a farm; this definition is rather an allusion to the Soviet realities (there are remnants of the "house of councils" on this farm, where the "red flag" is still streaming (Volodine, 2015: 97)).

The second utopian locus, the camp, does not have any certain signs at all, it is an idealized ghostly image: "No one can deny that the commune is the highest manifestation of dignity and organization for which the society of free men and women strives, who have sufficiently lost their animal status, to begin the liberation, moral progress and the creation of history. <...> Nothing can ever be compared with the commune, no architectural building created by a person or appropriated by a person will ever reach the level of harmony and perfection, the stability of the spirit in front of the fate that the commune gives to everyone living or dying in it" (Volodine, 2015: 212). Concentrated loci in the other A. Volodine's novels (the almshouse in the "Minor Angels", the commune in "Dondog", the Bardo tunnel in "Bardo or not Bardo") are utopian.

However, in the aggressive, dystopian, post-apocalyptic "post-exotic" world, the hope for the revival of human brotherhood is preserved: "Finally, we realized that the concentration system in which we were locked up was the last irresistible redoubt of the egalitarian utopia, the only place on the earth where the inhabitants were still struggling for your version of paradise” (Volodine, 2015: 65). 
On the one hand, the commune is idealized, utopian locus, the only possibility to continue human existence in the conditions of the fall of political ideologies and social revolutions. It is the commune that is a phantom goal, the ultimate station of "escape journey", to which Untermenschen, the remnants of mankind in the "postexotic" world, go: "The commune was about fifty meters away from the track. <...> I cannot believe it, he said. - Yes, we came at last, confirmed Noumak Ashariyev. It is incredible. <...> Hudzobol Munstzberg felt joy in his heart. His journey was over. A few hours left, some formalities - and it will be finished"(Volodine, 2015: 263-265). On the other hand, the commune appears to be only as a 'ghost' of salvation, a parody of another attempt of society to create a "paradise on the Earth".

Thus, at the end of the novel, "Radiant Terminus", the same desirable for Iliouchenko and his companions commune was depicted, but within seven centuries: "There was no railroad, its remains could not even be the mark for potential travellers from the steppe or the forest. In fact, nobody else made such distant trips - through regions and even continents, so there was no need for road signs” (Volodine, 2015: 432).

Thus, taiga seized those few expanses where the remnants of humankind survived. And Kronauer, whom Soloviei had captured for years (or he just was dreaming), realized one day that the door of his cell was open - but any life outside disappeared: "Broken or destroyed barracks were lining up in rows. They stretched for two kilometres and then merged with the surrounding landscape, and then there were only more or less noticeable roads, black shingles, swamps and fir trees, on which branches there were huge crows” (Volodine, 2015: 454).

This motive of the journey, the way to the utopian ideal, is repeated in the novels of A. Volodine in various interpretations. In the "Minor Angels", old shamans "wake up" Will Scheidmann to save the world - and he "runs without stopping <... , not lowering the rhythm neither in the day nor at night $<\ldots>$. In most cities that he visited, he met men and women who degraded and stayed in some kind of moral lethargy" (Volodine, 1999: 115) (which can be perceived as a metaphor for the fussy modern life of one and passive acceptance of circumstances of others) and eventually he himself became the creator of dystopia - "restored capitalism” (Volodine, 1999: 116).

In the novel Dondog, the protagonist wanders the labyrinths of the City in search of not only revenge but also of his own memories, trying to regain his living condition through the revival of memory, but in vain: "I was beaten on my head, but my memory dimmed. I was thrown to die. <..> To beat me, I said. - My memory dimmed. Forever, it fades away” (Volodine, 2003: 300). 
In "Bardo or not Bardo", the characters are already in a post-mortem state, wander through Bardo, trying to create their alternative utopia in a state of complete utopia (death): “One would have tried to build a world here.” Do you understand, Dadokian? I would have tried to linger in Bardo for an indefinite time. - Here? On this heap of sand?.. - Here or there, a bit further. It would be possible to build some kind of nice house, create a landscape... I studied the book very well. Here we are neither in space nor in time. Most images come from our imagination. If we succeeded in stabilizing them, somehow materializing around us, we would have rebuilt Bardo at our discretion. <...> - In fact, I do not know if we can create a paradise, - suddenly doubted Shmolovsky. - It depends... I do not know, no matter what it depends on, or who it depends on... Maybe on you, Dadokian, either on me or on our common ability... Gong” (Volodine, 2004: 191-192). But finally there turned to be no prospect of improvement: "The end of the trip is achieved, and Borschem did not understand anything. <...> There is no longer any prospect” (Volodine, 2004: 122).

Consequently, the utopian elements reveal the idea of the cyclicity and repetition of the mistakes of humankind, the inevitability of its degradation, provided that the trends outlined in the history continue. In the "post-exotic" world, the search for utopian ideals is an endless, cyclical process: in the conditions of the defeat of social utopia, the remnants of "humanity" continue to try to reach it in a state of non-life. But the inevitable return to "anti-utpia" is happening - all the novels state the defeat of revolutionary projects and the loss of hope for the attainment of the utopian dream.

Another specific feature of the Volodine's meta-utopia is the "realism" of the fictional universe - numerous references to the real world contribute to the reader perceiving it as probable and possible. Thus, the key characteristic of the utopian chronotope is destroyed as a non-existent place ("u-topia" - from the Greek "place which is not present" (Шишкина, 2007: 200). The "post-exotic” chronotope is only formally excluded from the diachronic process (the reception in utopia / anti-utopia is involved in the "stereoscopic examination modelled by the author of pseudo-reality" (Шишкина, 2007: 206). "U-Chronicle” as “a certain non-historical time” in the novels of A. Volodine acquires the form of an indefinite time, its orientations are replaced and confused, however, numerous allusions bring it closer to the historical reality that appears to be a possible future. The fantastic chronotop of "post-exotic" novels does not appeal to a particular locus (city, island) or the moment of the future; it is universal - an event can happen anywhere (parodying the "u-topia") and any time (parodying the "u-chronia"), but inevitably "after the collapse of communist ideals and their dystopian denunciations” (Huglo, 2003). 
However, collaterally with the defeat of the revolutionary project of the twentieth century, A. Volodine tries to find a way to avoid a total defeat of the "human project" in an artistic form. The utopian principles in novels are embodied not only in the plot and on the philosophical level. The writer raises existential problems of sense and existence of human being vut moves them to the realm of creation, writing; he develops the reflection on the possibility/impossibility of writing in the modern world, the possibility that it is possible to transform the reality via the creation processes.

Thus, "death of the author" as a key feature of the "post-exotic" narrative is, in fact, a dystopian principle (the assertion of defeat). And the creation of the imaginary position of the "super-narrator", which "continues not the existence itself, but the existence of those who will soon be extinguished, since he is the only one who still preserves memory" (Volodine, 1998: 13, 16), embodies the utopian idea of speaking/writing/creation/existence in a world that has suffered a utopia defeat.

Even in the "post-exotic" world, even if the author perishes, his works live: like in the story of the deceased Fred Zenfl who "could not accept the collapse of humanism" (Volodine, 1999: 29) and "contemplate the extinction of mankind to a greater extent, but relate to his own death as personality” (Volodine, 1999: 9). As well as Dondog, who wrote his Monologue Dondog (Volodine, 2003: 271) and stated at the end of life: "Satisfied or not, I have brought this life to an end. Everything has already turned into nothingness, and prose will survive” (Volodine, 2003: 339) or Bogdan Schlumm who continued to put on his "little plays", although "neither post-exotic theatre admirers, nor occasional viewers or other forest mammals did not attend his performances" (Volodine, 2004: 108). Thus, the utopian principles are embodied in the metatextual strategy of writing, the ultimate goal of which is to comprehend the meaning of not only existence in general, but also literature as a way of saving recollections, culture - and, consequently, humanity.

The creative aspirations are peculiar to the characters who exist in carceral environments: Soloviei’s daughter Hannko Vogoulian tries to "revive the prose" - "to restore memories of everything that was once read in small notebooks" (Volodine, 2015: 435) and finally creates his "post-exotic" literature - "Her works <... could be combined into a single, infinite cycle. They depicted the same dimming sufferings of women and men, their magical everyday life without any future, organic and political degradation, the endless resistance to death that they even wanted, constant uncertainty in the reality of being and carceral wandering of thoughts" (Volodine, 2015: 545). However, even when the "post-exotic" writer dies, he/she lives in others - "Either she or I, no difference" (Volodine, 2015: 547) - and hence, the figure of the 
writer is the embodiment of the "last barricade" of humankind in the face of ultimate decline and oblivion.

"Post-exotic" novels represent the society, "which overcame utopianism and, as a result, is deprived of memory and dreams” (Чаликова, 1994: 8). Such "postmodernist counter-utopia" claims new positions through "changing the structure of the characters, $\langle\ldots\rangle$ extending the tragedy in the state of personality, which loses the classical 'personality', <...> characters becoming 'non-people'” (Воробьева, 2009) thus, it do not deny, but reconsider the utopian idea. Consequently, A. Volodine's creative method reproduces the parameters of meta-utopia as a metagenre form. It has been seen in the analysis of the idea moving from the unmasking the negative tendencies of utopia to the restructuring of consciousness, as well as in absence in the novels "pseudo-perfect" world representation, the dramatization of consciousness, the mode of doubt, the juxtaposition of utopian concepts and tragic (dystopian and antiutopian) reality. Volodine's meta-utopia is an aggressive space of the "barbed-wired universe» (Volodine, 2003: 296), where people are looking for ways of selfpreservation attempting to build an ideal society, and the situation of its defeat incurring involution processes (moral degradation, physical transformation into animals, physical death and being in a state of non-life). "Post-exotic" novels give the idea of possible ways of development of society, not only based on the imagination of the author, but also on "his ability to trace the power lines of the era far ahead, relying on the real facts of the historical process” (Тимофеева, 1995: 10).

The novels of A. Volodine "Minor Angels", "Dondog”, "Bardo or not Bardo" and "Radiant Terminus" are hybrid genre-discursive forms that absorb features of fantastic discourse, elements of alternative history, political and oniric discourses. The writer uses the form of a fantastic novel in order to represent the irreal world, and by superimposing the elements of history gives it the character of the possible, vanishes the border between the fictional world and the real.

Elements of fantastic discourse, alternative history, political discourse are only the background for the deployment of socio-political reflection and rethinking utopian discourse on the merge of the $20^{\text {th }}-21^{\text {st }}$ centuries. The attempt to comprehend the tragic events of history is realized in the form of the postmodern novel: real historical events (world wars, proletarian revolutions, concentration camps, manslaughter) appear through phantasmagorical mutations of the chronotope and comprehended in the parameters of dystopia.

On the one hand, the "utopian" world can be considered as a reflection and/or parody of utopia, on the other - an update of its form in the context of the coexistence of the 
concepts of western pragmatism and eastern religious practices, that contributes to the attribution of "post-exotic" novels as meta-utopia. The form of the novels of A. Volodine is full of realistic content, comprehends the present days of the mankind and renews the tradition of the utopian genre. Analysing the trends in the history of the twentieth century and its tragic events, the writer claims the defeat of the "human project" and makes in his work the search for the way of survival of humankind in the situation of the collapse of utopian projects.

In the form of "post-exotic" novels there is a combination of elements of anti-utopia (the negative vision of society and the position of man in it) and utopia (rethinking the utopian principles of the universe and looking for the possibility of restoring "egalitarian" utopia), which predetermines their analysis in the parameters of postmodern meta-utopia as a metagenre form of utopian modus in the literary context of the $20^{\text {th }}-21^{\text {st }}$ centuries. The meta-utopic nature of A. Volodine's novels is enhanced by the metatextual strategy, the reorientation of philosophical reflection into the spheres of writing, creativity, and the preservation of collective memory as the only possible way for the human community of salvation.

Consequently, the philosophical, socio-political and historical problems of "postexotic" novels, realized by means of combining the features of fictional and real in the "post-exotic" fictional world, parodying the genre canon and the combination of discriminatory elements, show that novels of A. Volodine reinterpret the tradition of utopia and anti-utopia in the form of meta-utopia using the postmodern narrative tools and updating the literary context of the late $20^{\text {th }}-$ early $21^{\text {st }}$ century.

Submitted on 21 October 2018.

\section{References}

Безчотнікова, С. В. (2008). Російська літературна антиутопія межі XX-XXI століть: динаміка розвитку, вектори модифікацій, типологія. Д-р філол. наук. Київський національний університет імені Тараса Шевченка.

Бовсунівська, Т. В. (2010). Когнітивна жанрологія та поетика. Київ: ВПЦ «Київський університет».

Воробьева, А. Н. (2009). Русская антиутопия XX - начала XXI веков в контексте мировой антиутопии. Д-р филол. наук. Самарская государственая академия культуры и искусств.

Детю, Ф. (2008). Антуан Володин: портрет художника-сталкера. In: А. Володин. Малые ангелы. Москва: ОГИ.

Ковтун, С. Н. (1999). Поэтика необычайного: художественные миры фантастики, волшебной сказки, утопии, притчи и мифа. Москва: МГУ.

Козьмина, Е. Ю. (2005). Поэтика романа-антиутопии: на материале русской литературы ХХ века. Канд. филол. наук. Российский государственный гуманитарный университет.

Подлубнова, Ю.С. (2007). Метажанры, мегажанры и другие жанровые образования в русской культуре. In: B. М. Головко, Герменевтика литературных жанров. Ставрополь: Ставропольский госдарственный университет. 
Тимофеева, А. В. (1995). Жанровое своеобразие романа-антиутопии в русской литературе 60-80-х годов XX века. Канд. филол. наук. Российский университет дружді народов.

Федух, I. С. (2015). Жанр антиутопії у постмодерністичному дискурсі. Актуальні проблеми філології та перекладознавства, Вип. 9.

Фуко, М. (2004). Археология знания. Санкт-Петербург: ИЦ «Гуманитарная Академия».

Чаликова, В. (1994). Утопия и свобода. Москва: Весть.

Чаликова, В. А. (1991). Утопия и утопическое мышление. Москва: Прогресс.

Шервашидзе, В. В. (2007). Тенденции и перспективы равития французского романа. Вопросы литературы, [online] №2. Available at http://magazines.russ.ru/voplit/2007/2/sh7.html [Accessed 28 Jan. 2019].

Шишкина, С. Г. (2007). Литературная антиутопия: к вопросу о границах жанра. Вестник гуманитарного факультета ИГХТУ, [online] №2. Available at https://www.isuct.ru/e-publ/vgf/sites/ru.e-publ.vgf/files/2007/vgf-200702-199.pdf [Accessed 28 Jan. 2019].

Шишкина, С. Г. (2009). Истоки и трансформации жанра литературной утопии в XX веке. Иваново: Ивановский гос. Химико-технологический ун-т.

Braga, C. (2006). Utopie, eutopie, dystopie et anti-utopie. Metabasis. Rivista di filosofia, [online] №2. Available at http//www.metabasis.it/articoli/2/2_Braga.pdf [Accessed 28 Jan. 2019].

Briot, F. (1995). Les Chimères d'Antoine Volodine. Roman 20-50, №19.

Cioranescu, A. (1972). L 'avenir du passé: utopie et littérature. Paris: Gallimard.

Epelboin, A. (2013). L’utopie de la fin et la fin de l’utopie. Littérature, Histoire, Politique, №8.

Huglo, M. and Wagneur, J. (2003). The Post-Exotic Connection: Passage to Utopia. SubStance, Volume 32(2).

Lamarre, M. (2014). Ruines de l'utopie. Antoine Volodine, Olivier Rolin. Villeneuve d'Ascq: Presses universitaires du Septentrion.

Morson, G. (1981). The boundaries of genre: Dostoevsky’s Diary of a Writer and the Traditions of Literary Utopia. Austin: University of Texas Press, 1981.

Richard, C. (2012). Politiques de la littérature, politiques du lien chez Antoine Volodine et François Bon. Paris: Archives cotemporaines.

Roche, A. (2013). «Vrai à cent pour cent ». Itinéraires, [online] Volume 2013(1). Available at http://journals.openedition.org/itineraires/838 [Accessed 28 Jan. 2019].

Ruffel, L. (2007). Volodine post-exotique. Nantes: C. Defaut.

Volodine, A. (2004). Bardo or not Bardo. Paris: Seuil.

Volodine, A. (1999). Des anges mineurs. Paris: Seuil.

Volodine, A. (2003). Dondog. Paris: Éd. du Seuil.

Volodine, A. (1998). Le post-exotisme en dix leçons, leçon onze. Paris: Gallimard.

Volodine, A. (2015). Terminus radieux. Paris: Points. 